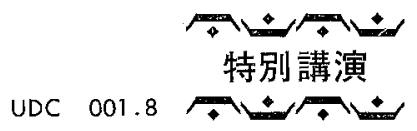

周辺の学問と技術の問題

大 島 惠 —*

\title{
Technological Innovation and Related Issues
}

Keichi OshIMA

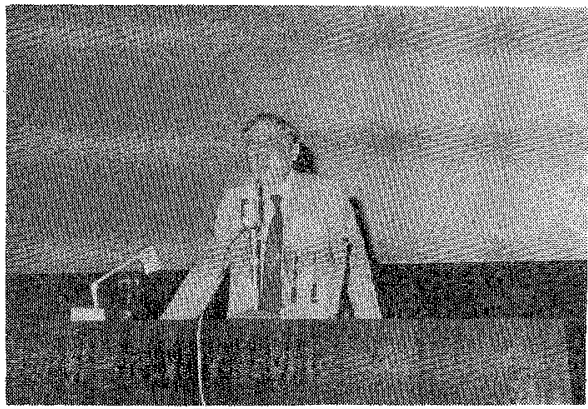

1.はじめに

ただいまご紹介にすずろりました大島でございま市。 本日は，稲山会長，宾戸理壶長から，鉄鋼業飞関する 諸問題の打話があつたかけでございるす，次に私は，技 術，及び学問の開題を特話しすることになつて机ります が，きう，こちらへ参りまして，鉄鋼協会の発表論文 集の厚い本を排㒻しまして，たいん感心致し未した。

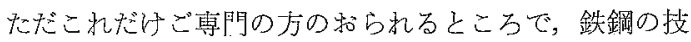
術の将来と今後の問題老和話しするのは，とても不可能 であると思つた次第です。，たまたを気がつをましたら， せいわい「周辺の」といら演題をつけていただいて括り 丞すので，鉄鋼といらよりは电つと一般的な形で，現在 世界の経済のみならず，补会全体が一つの大をな転換期 にぶつからている時に技術非よび研究開愽の問題が，ぞ

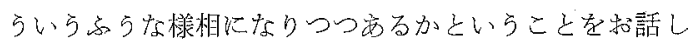

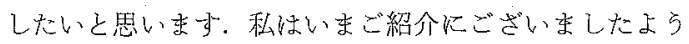

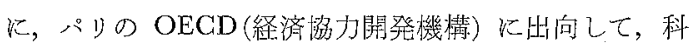
学技衍工策局の仕事をしてまいりました。それで最近 OECD 加泏里した報告畵「Technical Change and Economic Policy」の内容年中心, OECDの科学技術 政策委員会の活勘などをご紹介しながら，私なりに今後 の技術開発の問題点について考えておりますことを述心゙
させて頂きすす。

日本では科学技術の中での技術政策というのは，古く 明治開国の当初からあのたわけでございまして，今まて の話にもございますよらに，それが実を結んで戦後，日 本ま見芽に欧米に持くれていた技術格差を埋めて，現在 の世界的にすぐれた産業技術体系をつくりあげたわけで あります。

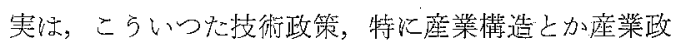
策の関連に打壮る政策といらものは，日本では大变あた りまえの重と考光ますが，私が 1974 年飞 OECD 参

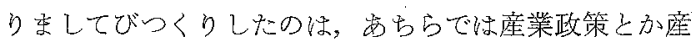
策構造といらことについて大変消極的で，大体産業とい うものは政附の政策などでつくるものではなくて，自然 にでき上がるるのたといらことを言わ机たことです。

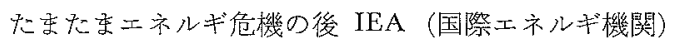
が設立され，それにともなつて OECD のエネルギ工業 局が再編成されて工業が私の担当の科学局と一緮に統合 されて科学技術工策局になつたのですが，艺の発足に当 つて, 事雅総長ヴァン・レネップ氏のとこるに四ばれたわ けでございます・「工業孝貿易局と一緒见しよらかと思つ たけ机どる，そ机で保護的になる恐机が岁つてまずい。 工業の新しい発唇考克れば，技術こ气大事なのでこの よらに決めた」といら話があつたわけであります、私は， 戦後の通産省の技術政策にかなり関係していた経験が蛒

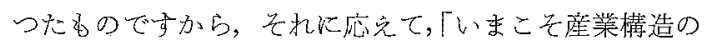

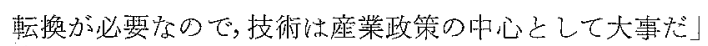
亡言つたらヴァン・レホップ氏は苦い顔をしまして， 「産業構造政策は日本のノートリアス一一と違つてそ のころはノートリアスと言われていましたけれども一な通産省加やつたことで，ヨーロッパは各ううをくはい

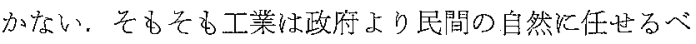
きで，そのために政府は技術を強くし，経済的な条件を 整えることに専念すべきだ」と言つたわけであります。

け礼ども，实際にはそれから数年足らず，私がきだ 
OECD にいるうちに，OECD 各国も産業構造政策と いらことを言い出しまして, 現在ではむしろ PAP (Positive Adjustment Policy) と称して産業構造の前向 きないわゆるポジティブな調整ということが，OECD の一つの主要課題になつてきているわけであります。そ れで，先ほどの括にもあつたよらに，各国から日本が 一体どうやつたのかを見に来るといら現状になつていま 与.

これが現状でありますが，外国から見て日本の技術並 びに産業の一番すぐれている点は, 非常に適応雀が早 い，いわゆるフレキシビリティーが高いといらことで す。先ほどのグラフにもございましたが，エネルギ危機 の後, 外界の変化に応じて省エネルギと申しますか, エ ネルギ原単位を一番早く減らしたのは日本であります。

実は，日本の為替が急に円高になつたときに，たまた ま通産省関係の各企業の方々のヒヤリングに列席をしま したが， 1 ドル 200 円を切ると，エレクトロニクス，自 動車を合め, 日本の産業は全部つぶれるよらなご説明が あつた㹨です。ころが，後で個人的に実際に技術の 担当の方に，「本当ですか」と聞きますと，「いや，絶対に そらいらことはありません，われわれはどんなにがんば つてでも国際競争力には勝つ自信があります」とひそか に抽しやつたわけです。乘際にはその方が事実になつ たわけであります。

また，私が記憶しております一つのエピソードがござ います，OECD から国際エネルギ機関事務局長ランツ ケ氏が参りまして，日本で講演をされた時です。たしか 1975 年で，すでにオイル・ショックの後かなりたつて おりました。いろいろ世界のエネルギ事情, IEA の活動 を説明し，最後に何か質問はというと，聴衆の 1 人が手 を挙げて「日本は世界で最も石油に対する輸入依存度が 高く，日本の産業にとつては，エネルギ俩格の」:昇は致 命的である。あなたは，日本がどらやつてこれを乗り越 えたらいいと思いますか」といら質問をしました，ラン ツヶ氏がびつくりして，「いや，月本はもら乗り越えてい るんで, 尖は私は, 日本がどらやつて乘り越えたかを勉 強するために来たんだ|と言われたわけです，そのくら い月本の方は，日本が大変だと思つているわけですが， 外国はもつ之大変なんで，日本は非常にらまくやつてい るおけです。

先ほど突戸さんが自動車の技術の問題にふれましたけ れども，私もフランスで自動車業界の人に会つたとき に,「日本を訲問して日本の技術に大変感心したけれど も，一番驚いたのは白動車のラインの拈しまいで，職工 さんが終わると走つてもとの場所一戻る。フランス人と いらのは，普段街を歩いていてたとえ信紊が赤になつて も絶対に走らないのに，工場の川で職工さんが仕事のた めに走るなんていらことは，絶対に考えられない，ああ いらことは、どうして日本ではできるんだ.」き言つて
いました・結局，マネージィントといいますか、䇰狢管 理といらよらなことになるのかもしわ来姑んが、てんな 話が出ていたわけです。

ただ，私は，この問題では幾分只けさんと㤩见が造り のでありまして，日本のそういら職 Iささんが，北常に忠 実に働いて QC 活動などを熱心にやんたりするという ことが，一体いつまで続くかには，やつぱり人きな阔題 があるんじやないかと思います。もまた九，外目よりは 続くでしようけれども，私は学狢管理に上る技術には限 界があつて依然としてハードウェアと川しますか，技術 そのものが，今後とも基本们には大きな顿装州をを掠つて いると思つているわけです。

もつとも，成田空港が学:牛や成刘派のデモで䦌鎖にな りそらだといらときに，たまたまバリに拈りましたら。 フランス人が，「これは大変いい徵候だ，川本でもブ ンスなみにデモで空港がとまるといらことがあるなら。 先々日本でもいわゆる勤勉な労働若はいなくなる」と、 つていたのですが，何とそのデモも3川ぐらいでさい之 終つてしまつたのです。今後どういらふらに変わつてい くか知りませんが，かなり社会が変才つていくだるら上 思うわけです.

それではスライドを扮見せしながら拉ししていきた いと思います。

最初に，OECD での科学政箖についていしますと，

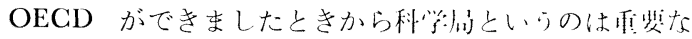

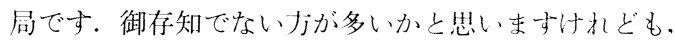

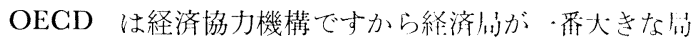
ですが，その次に大きいのが科学:尚だつたのです。私の

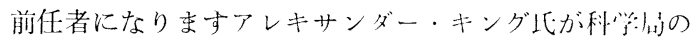
創設者ですが，初代の事狢総埌クリ久チャンセン比も非 常に技術問題を重要視されまして，1960 作に符1 以の

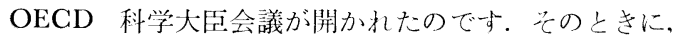
ヨーロッパでは初めてと言つていいと思い方が、科兴 技術を国家目的としての経済成垃のために役的て友政籍 をとらなければならないと強く訴えたれけです。旧で は，先注ど秃しましたよりに，明治の初るから科受技術 は富国強兵策のための最車装政策のいで，人兴にしま しても学部が初めからあつたわけで、これはあたりま

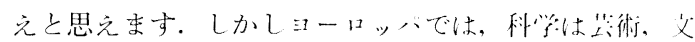
学などと闹じでありまして，てもそも目の政箖とか経济

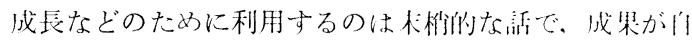
然に流れ流孔て役に市つのはいいけれども，それを的 とする政策をとるのは，科学に刘する傎であるぐらい に考えていた人たちが多かつたれ忛です，川本でも，幾

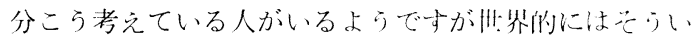
ら時代があつたわけであり亦す。艺れに対して、OECD は科学技術政策といらことを強く打七恬したれけです。

ところが，1960 伴のの終わりから70 作のの初めになり史

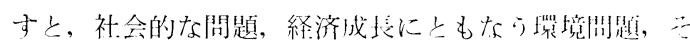


の他科受技術のいわわるソーシャル・ディメンションと OECI）で占ばれる課题がでてまいりまして，これに関

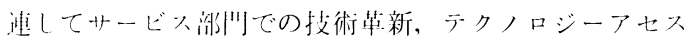
メント，さらに䄄补といらよらな話になつた㧅けです。 これが，70 伴代の科学技術政策として 1971 年の第 4 回 大阣会議のけ心になりました。 1975 年に第 5 回の科学:

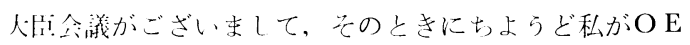
CDにいたねけです.このときには，不油危機以後の新 しい転換期を技術によつてどら乗り越えていくかが.つ の課題にならたおけけです。

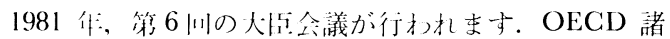
|同が今後の壮界の、社会的, 経済的転換にどらこたえる かということが科”学技術政策でも大きな1:題になるわけ です、てのときに，先汪どから中している上うに「日本

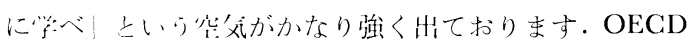
ではそのの胿によのていろいるなキャッチフレーズがござ いまして、いま科黄技術政策では, “ピッキング・ザ・ウイ

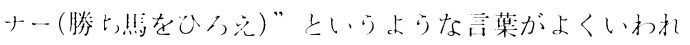
ます。どこかの人怙が辛つたらしいんですが。“ピッキ ング・将・ウイナー”にいのはどらいらことかといら

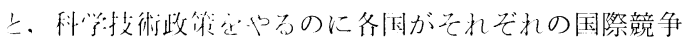

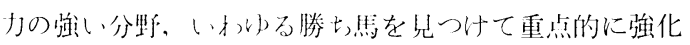
しよら々いらのです. 川本がたとえば鉄鋼から自動車,

またエレクトロニクメと, そらいら勝切馬を次々と見つ 计て、政行が研究阙発完助成して成功した。 そ机で各国 も，分の相の勝七结を思つけて间じような政策をとる べきだということなのです。

私はとれを班きまして川本の衙は少し違らといつてい

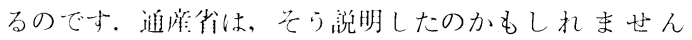
が，私ども笛から技術政箖に携わつている者から見ます 之, 览は円本は勝七,照を見つけたのではなくて, 競馬場

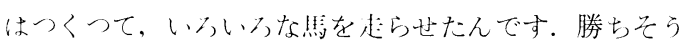

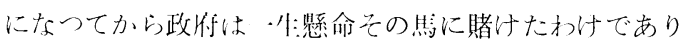
まして、初かからどの悲が勝つといらのは分つていなか つた。 人体新楒でも, 勝つた人は初めからあれは勝 つとわかいていたと、られけですが もしもどの䲱が 勝つかあらかじぬれからてい机ば，通産省の抢役人は又

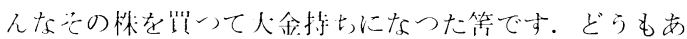
来りてらいらららに儲忛たといら人も聞きませんので,

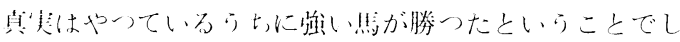
よ。.

ではどうして川本の技術政策が成功したかというと， 幾つかの条件があのたと私は思らのです。

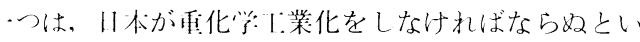

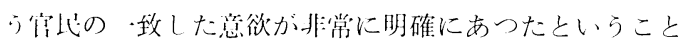
です。ただし具体的にどらやるかについては，議論がか なり分かれていたれけです。たとえば，外国技術を導入

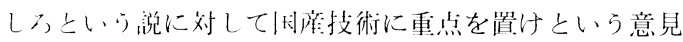
があり史にたに，輸人制限に対して内目競争といら意見
がある、それを文んな，どれがいいのかわからないの で, れでもない,これでもないとやつていたんですが， 何かやろらといら意欲だけはありました。

第 2 は, 高度成長の時期であつたために，やり直しが きいたということがあります。実は私は化学の出です が，たとえば化学工業のいろいろなプロセスを見ており ますと，技術導入でも国産技術でもかなり投資をして失 敗した例もずいぶんあるのですけれども，高度成長期 で，2，3 年たつと次の設備投資が必要になつてきます から，どんどんやり直しがきいた，日本の技術政策もい ろいろなことをやつた中で，いい政策だけが有効な形で 残つていつたといえる。これは低成長期には不可能なこ とだと思います。

第 3 は先汪どの稲山会長のお話を伺つて強く共感した のですが，やはり競争と協力といらのが非常にらまくで きていた，アメリカでは競争を促進するため独禁法があ りますが, そのため, 研究開発での協力ができにくい。 クッン政権になつてすぐだと思いますが，アメリ力議会 が日本の技術政策を重要視して，ヒヤリングがありまし て，私が出席して説明したことがあります。そのときに アメリカでの論議の一つは，独禁法がアメリカの技術を おくらせているのではないかといらことがありました。

日本は鉄鋼でもエレクトロニクスでも共同して研究開発 をやる．日本でもそれなりの法律などが必要のようです が，独禁法を免除するよらな形ができるわけです。 ヒヤ リングでもアメリカの法務省はかなりきつい立場をとつ ていて，たとえば環境問題などに関する研究開発でも企 業が一緒に協力することは技術の進歩を妨げる，新しい アイデアがでても独占しているグループにおさえられる 恐れがあるといらような話をしていました。

また独禁法によるとある企業が非常にいい発明をし， 製品が売れて市場をふやしていくと，技術を公開しなけ ればいけないといらことが義務づられているわけで す.これは企業の新製品開発の意欲を失わせることにな る.アメリカの政策はなかなかイノベーションにつなが らない。月本の場命はその点がら本くいらていたと思う わけです.

\section{OEGD の科学技術政策}

まず OECDの科学技術政策がどらいらららに変わつ たかを大臣会議を中心に表1で拈見せします。

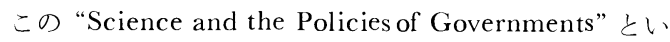
らのは OEGD の科学大臣会議のときに出された基調報 告書の題名であります. 第 1 回は 1960 年で, このとき 日本からは，未加盟国であつたのですが，佐藤総理が当 時の科学技術庁長官としてオブザーバーで出席していま す。そのとき経済成長のための科学政策がらたわれたの です。これをらけてその後，OECD では，いわゆる技 術格差がつつの課題になつています。技術格差といらの 


$$
\text { 表 } 1
$$

1961

第 1 回 OECD 科学大臣会議

"Science and the Policies of Governments"

1971

経済成長のための科学政策

第 4 回 OECD 科学大臣会議

"Science, Growth and Society"

科学技術政策に打ける社:会阔題

1975

籁 5 同 OECD 科学大臣会議

"Science and Technology in the Management of Complex Problems" 変化一の対応の科学技術政策

は，アメリカとヨーロッパ，日本との間の技術格差で， これが非常に大きいので，何とかそれを埋めるための政 策をとるべきだといらことです。それに関していわゆる ビッグサイェンスも問題になつたわけです.

他の課題は，イノベーション，技術革新のための政策 で科学技術政策委員会および当時の科学局の研究の中心 になつていたのであります。

1971 年の大臣会議の議長は, 日本の科学技術仃長官平 泉涉氏がなさつたのですが，そのときの基調報告書は “Science, Growth and Society”といらことで「社会! といら言葉が出てきます。先ほど申しましたりーシャ ル・ディメンションといらことで，ただ高度成長が目的 ではない，成長のための成長ではなくてよき社会，福祉 のための成長という目的があるのだということです。

その後の OEGD ではテクノロジー・アセスメント， 医療とか交通など社会関連の技術，情報産業のプライバ シーの問題など社会的な問題が主要課題になつてきたわ けです。そのころからの大きな変化として各国の宇宙開 発や原子力などのいわゆる大型プロジェクトに対する投 資が少なくなつてきたことが指摘できます。

第 5 问の OECD 科学:大臣会議の主題は “Science and Technology in the Management of Complex Problems”といら，いわば複雑な世界の変化一の対念の 科学技術政策ということです。実はこの題名を OECI の理事会に出しましたところが，大体外交官の方が多い ものですから，一体これは何を意味するのかわからな い，数学:のもずかしい問題を科学技術で解くのかとか言 われましたがー。

いずれにせよここ大臣会議の絬果, 幾つかの重要な研 究がなされております。一つは発展途上国への技術移転 の政策です。もらつい，このときから初めて OECDの 科学技術政策委員会と工業委員会が合同で，釐業の転換 のための技術政策の作業グループが作られ京した。これ は産業構造転換に対する科学技術政策といらことです。
さらに，「新たな 経済社会条件下における科器技術

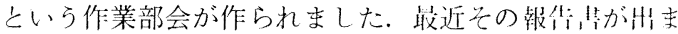
したが，この内容についてはあとでふれます。

\section{OECD 諸国の研究開発と日本の特徵}

さて，図1は各国の研究開発投资のカーブですが，大 体 1970 年代に入つて备泪の研究開発投资は低洲してお ります。日本と西ドイッだけは伸びており，川本は非常 に唗してト昇していると棓え史す。

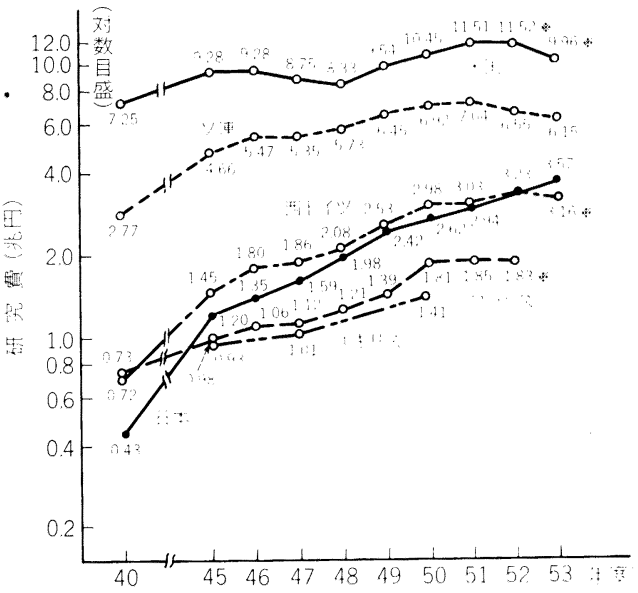

泣) 1.*は推官值である。

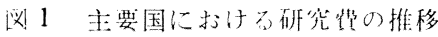
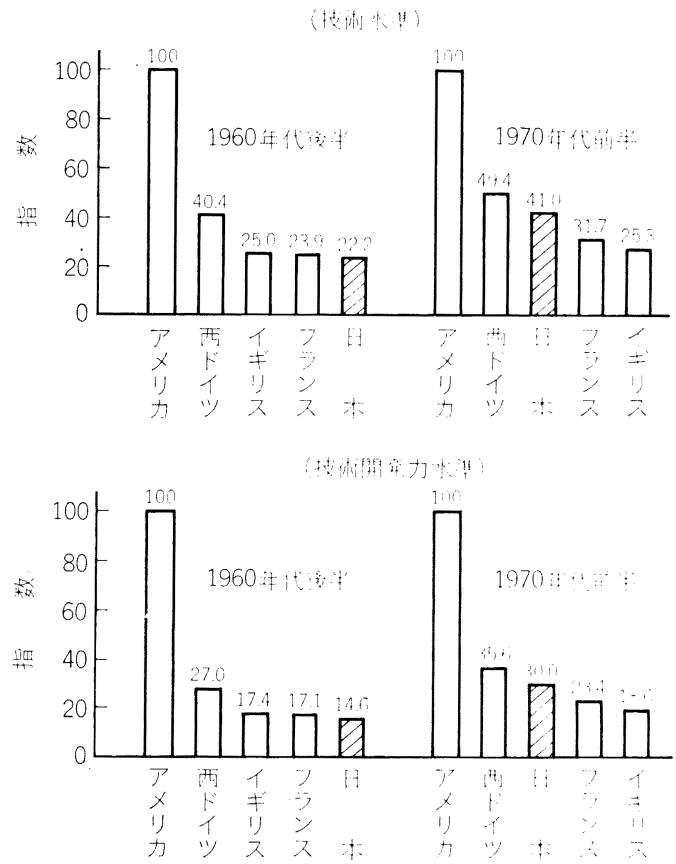

汹 2 主要国の技術水謴打よび技術開発力小潗 
たた，注川けずきことは，1973 什がエネルギ危機です か，エネルギ危機以後にアメリ力の研究開発投資がふえ て抢りますが，史大聂近トがつてきて拉ります。

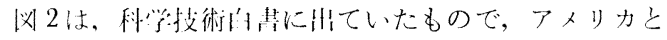

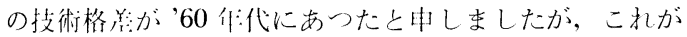

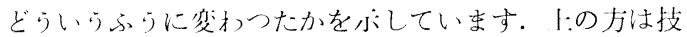
術水淮:で，卜は技術開焱少です。明らかに’60 年代と'70

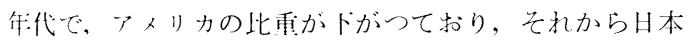
の技術ノが师倒的に菖くなつてきているといえます。

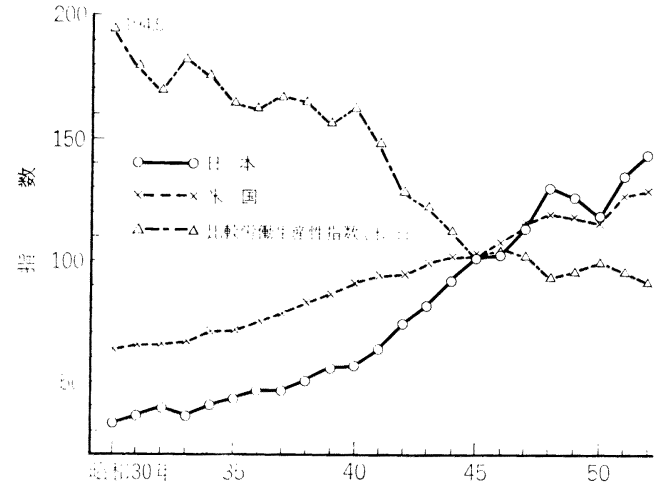

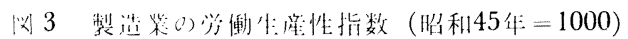

汹 3 は，日本とアメリカとの労働生産性の比較です. 1970 年で生産性が逆転するという事実があるわけです。 このよ5に’60 华代でいわれた技術格差とい5ものはな くなつて，むしろアメリカに対して，日本，ヨーロッ心 諸国の技術が競争的に高くなつたといらことが言えるの です．特に日本の技術が非常に高李つたわけげす。

それでは日本の研究開発投資はどらであつたかといら ことですが，为 4 は OECD 各国の産業における研究開 発投資の内容を示した戍であります。

国が A， B，C，Dと分けてあります。Aは，フラン ス，イギリス，アメリカでありまして，㧑の左のグルー プに来るわけです，Aグルーブは産業の研究開発投資が 航空機などの先端産業の才に偏つています。 Bグループ は一般的な産業でありまして，大国では日本と西ドイッ がBグループに入つて拈ります．Ｃグループは図の上の 方にありますが，ポルトガル，ギリシャなどで，サービ ス七クターに依存している国です。Ｄ尚ルーブが，二ュ ージーランド，アイルランド，アイスランドなどで，こ 机は食品とかたばこなどの産業グループです。

これで見ますと，日本産業の研究開発投資は，OECD 諸国の中で真ん中にきて扣ります。体は先進工業国と して非常にバランスのとれた研究開発がなされたといら ことが言えます。

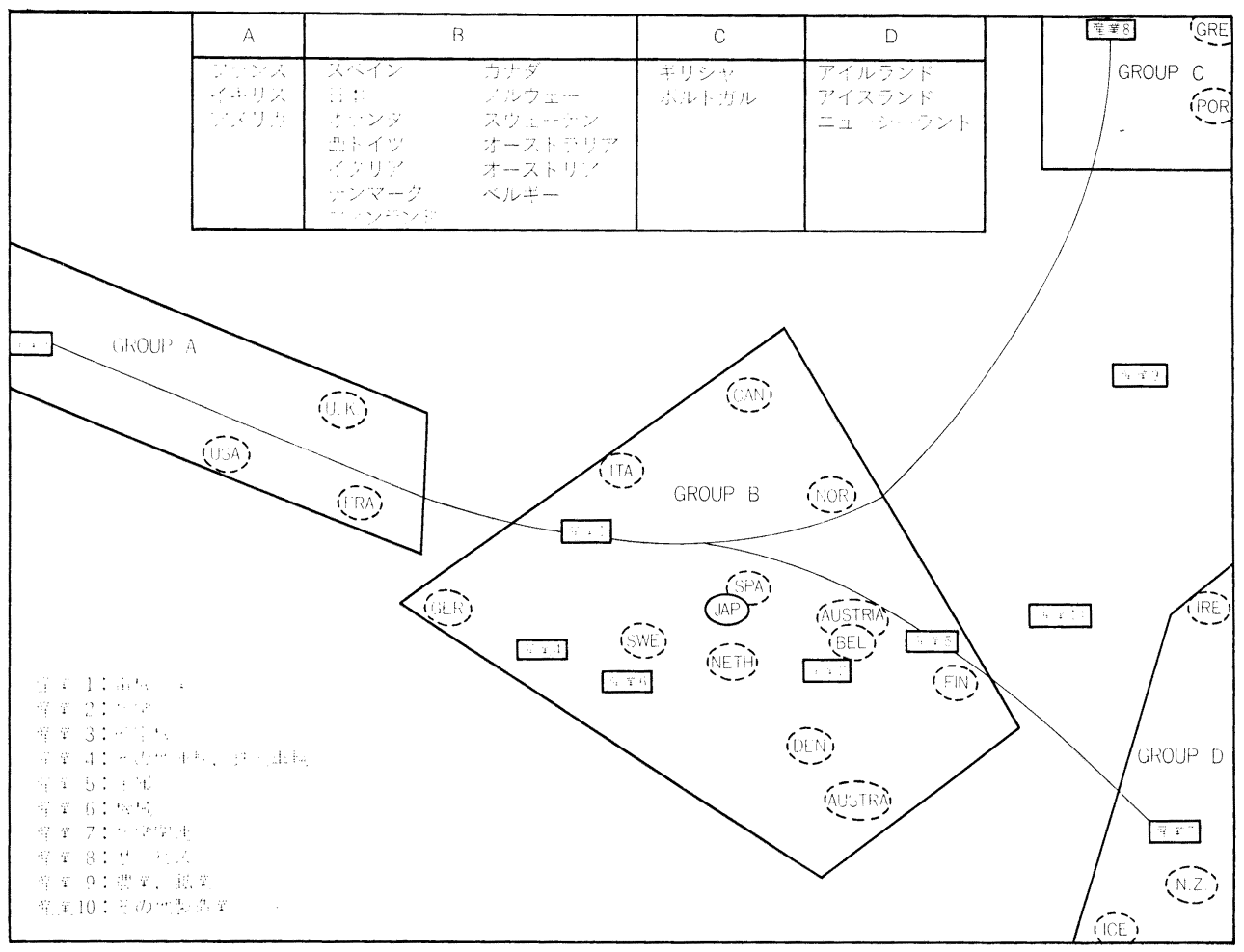

汹 4 坚柴別研究阙発の動向 


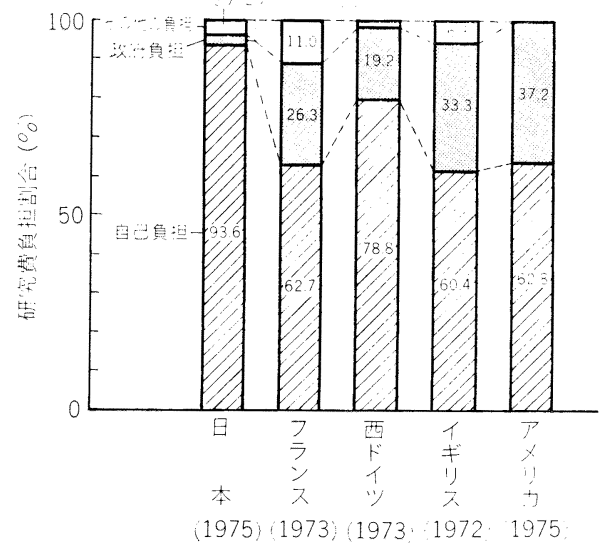

図 5 産栄部門における研究費の傎担割合

その理由はいいら考えられますが，よく言われてい るよ5に，日本産業の研究開発費のうちの政府負担が非 常に少ないわけです(図 5 )。西ドイッもフランス，イギ リス，アメリカに比べては少ない。ですから，日本産業 の研究開発は産業が自分の判断で自力でやつたといえま す.フランス，イギリス，アメリカなどは軍需とか航空 機とか，国家目的の力向に大きな研究開発投資が行われ ていたのです，日本のバランスのとれた産業技術開発は こらいらところから来ているのではないかと言えます。

日本ではいままで，政府の研究開発投資の分担が少な いのはけしからぬといら議論でしたが，OECD の解釈 はど5も，そのことが少なくとも1960 年代には日本の 産業技術にとつてプラスであつたといら解釈をしている わけです，政府と民間の研究費の分担割合は，軍事を除 いても，ドイツさ光政府の割合が $50 \%$ を超しているは ずです。アメリカなどは 70\%ぐらいになつていると思 います。ですから，戍6に示すよらな山本の $30 \%$ とい ら割合は非常に少ない数字です。

\section{4. わが国における 1960 年代の技術開発}

次にH本の研究開発はどらいらららに行れれてきたの かといらことです. 日本は重化学工業化一進んでいつた わけですが，そのときに外泪技術導入で令甘をつくりた と言わ㧈ています。しかし統計（汹７）を見ますと，日 本の技術といらのは，単に外国技術を導入しただけでは なくて積極的な自主的な研究開発活動が同時に行われて いるのが分かります。

H本の技術導入と门的な研究開発とは湾接に関連し ていて導入技術はただ導人したんではなくて，大きな生 産目標の中の研究開発投資の一環としてなされたという ことがいえます。

図 8 は, 右側は産業別の技術貿易の技術輸入の数字で

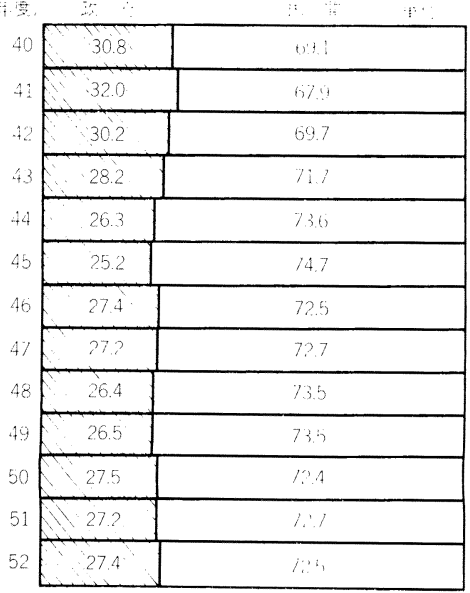

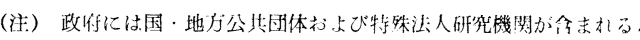

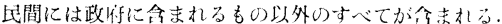

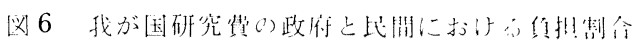
の推移

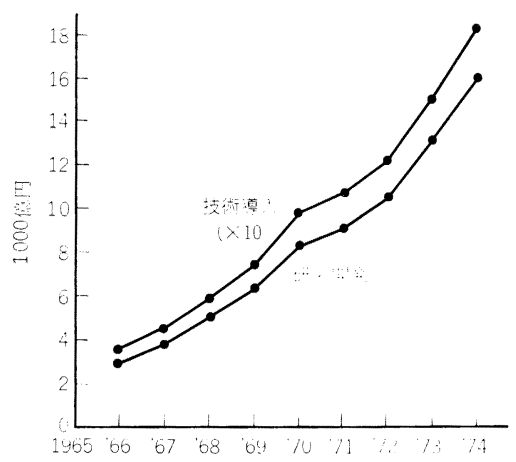

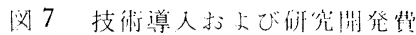

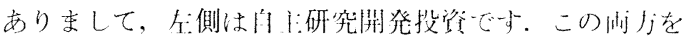
見ますと，七クターがほとんど间じであり亦す、古なお

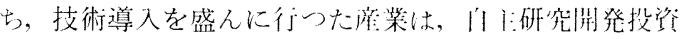
も杂机此例してやっているおけです。

ただ技術輸出になりますと，食く違うれけであり东し

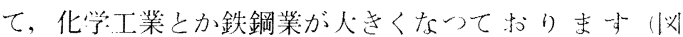

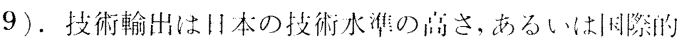
な経済協力，海外投资とい5ものと閲連があるおけであ ります。たとえば鉄鋼業などの埸命には，海外に出てい る技術はブラジルなど日本が絴济協ノをしているとこウ に大きくなつて拈ります。

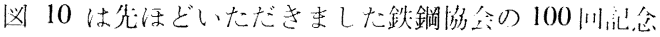

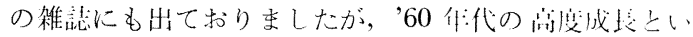

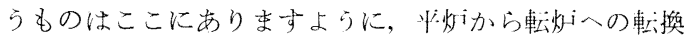

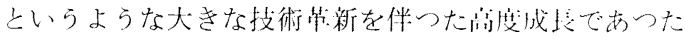
ことが特徵だつたといえます。 


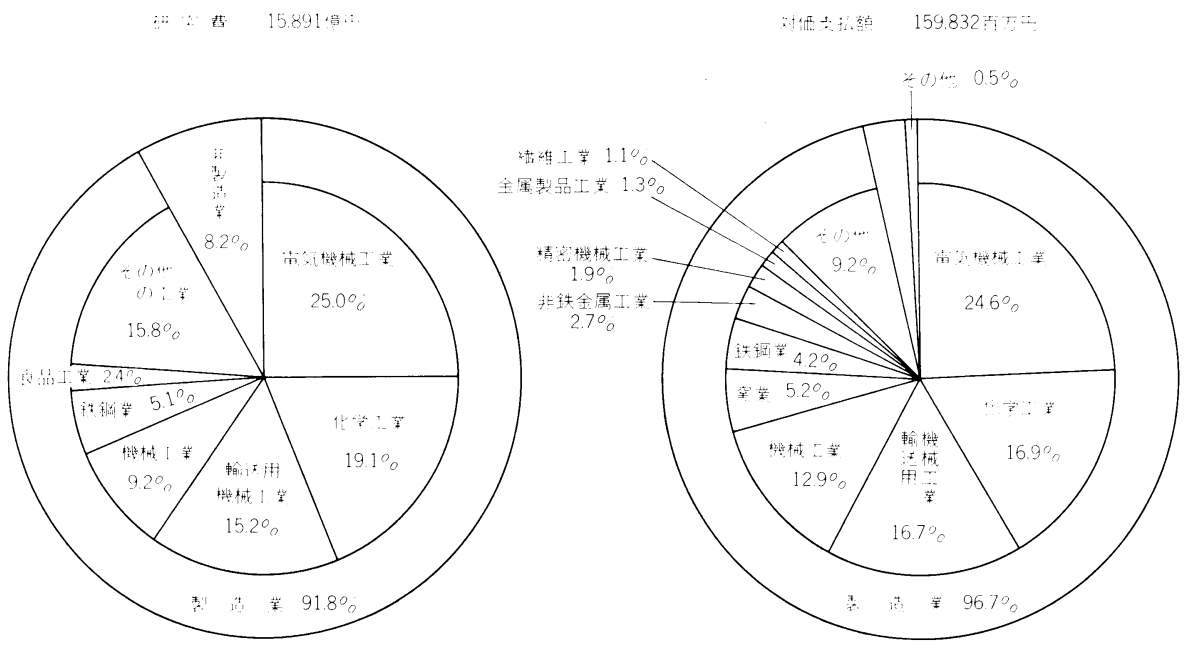

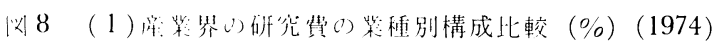

（2）我が[目の産箖別技術貿易の内沢（1974）

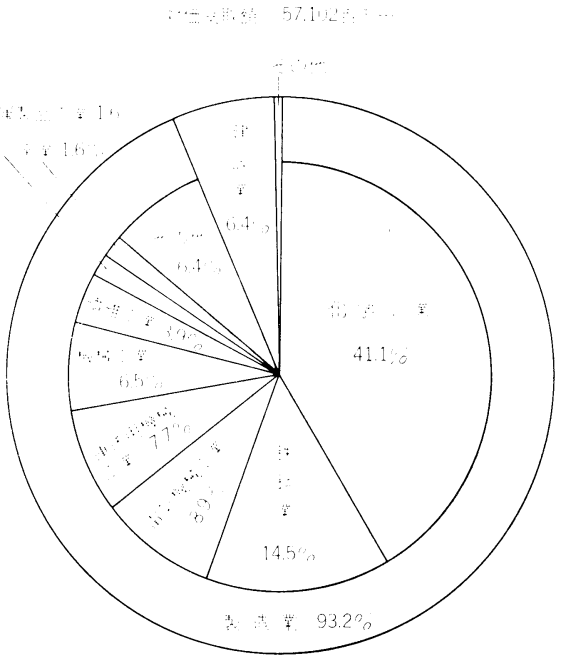

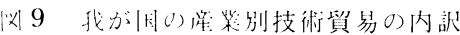

(1974)

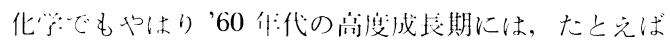

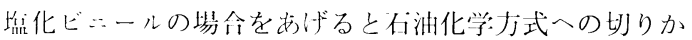

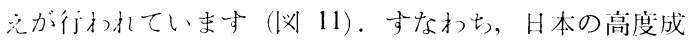

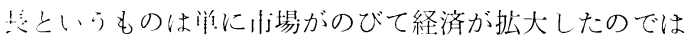
なくて，技術龩新を伴つたものであります。

汹 12 は齐稙栄業の伸びですが，産業構造が変わつて いたたとを小しております。，大きく伸びているのは，

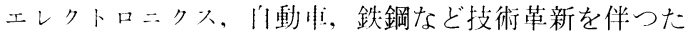

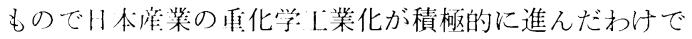
あります。

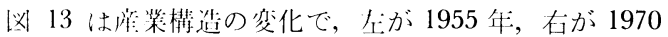

作です，第一次産業が伸び，重化学上業化が進んでい屯 寸。第一次産業は小さくなつて第三次産業は，余り変わ つていません。

貿易の方も大きく変化しておりまして，1955年に日本 の輸出貿易の大きな部分を占めていた繊維産業が小さく なり，機械，金属，化学など重化学工業化しています （図 14）。世界全体の貿易構造が重化学:工業化していつ たときに，日本の輸出も産業の重化学工業化を背景にし て，非常に伸びていつたのであります。

大学のことを申しトゲないと片手落ちになりますが， その間大学の理工系の学生数が 1960 年代に伸びており ます (図 15)。就職率は 1975 年以降低い状態に低迷乙 ておりますが，技術者でない職種への技術系の学生の就 職が増えています。ももちん就職者の絶対数はかなり伸 びているわけです，大学の教育の内容としては，いまま での研究者を育てる方向から技術者として専門知識を持 つ人たちを教育することが要請されました。この両者を どらいらバランスで教育するかということは一つの命題 で現在でも大学教育の問題点になつております.

往々, 皆様から最近の大学卒業生が技術屋として】場 の運転や技術改良には大変役立つが，創造的な革新技術 の開発については弱いといら意見を聞くわけですが，こ の数字でもわかるように，理工系の学生も増えています し戦後の教育の目的にも問題があるわけです.

㲸 16 は, 産業構造として 1975 年以降，第三次産業 が月本でも急速にふえていることと第二次産業がこれに 対して少しトがりかけていることを示しています。

以上非常に駆け足でございましたが日本の技術が1960 年代から 1970 年代にかけて，世界でも非常に二ニーク な形で生産技術を伸ばし，技術革新による産業構造の変 


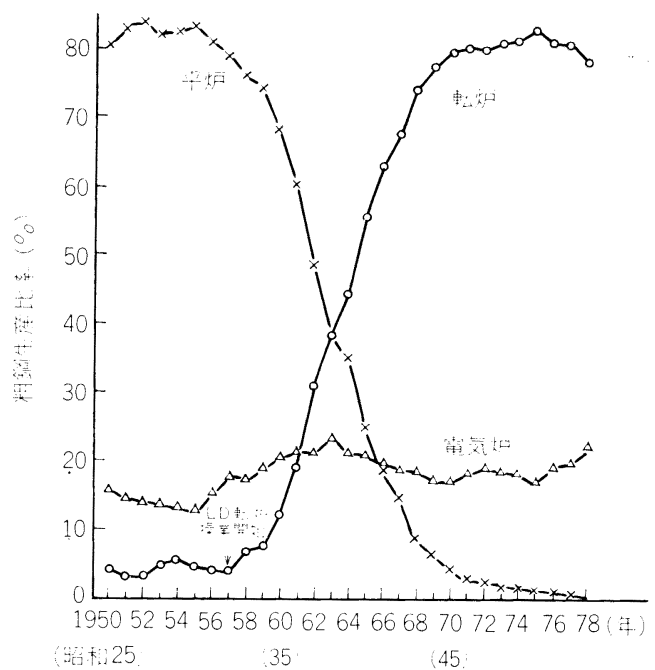

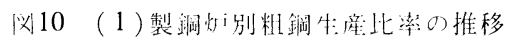

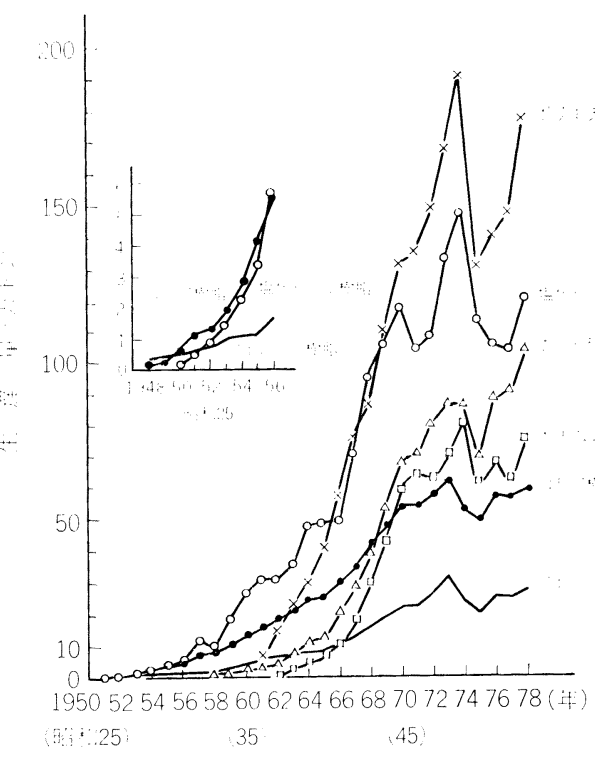

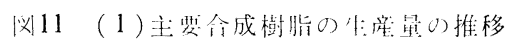

化を進好をたといらことを小したおけけです。

\section{OECD 報告による 1970 年代の技術革新}

先ほど山しました OECDの報告斯によつて先進」業 国における 1970 伴代の技術革新がどらであつたかにつ いて肘げます。

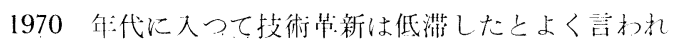

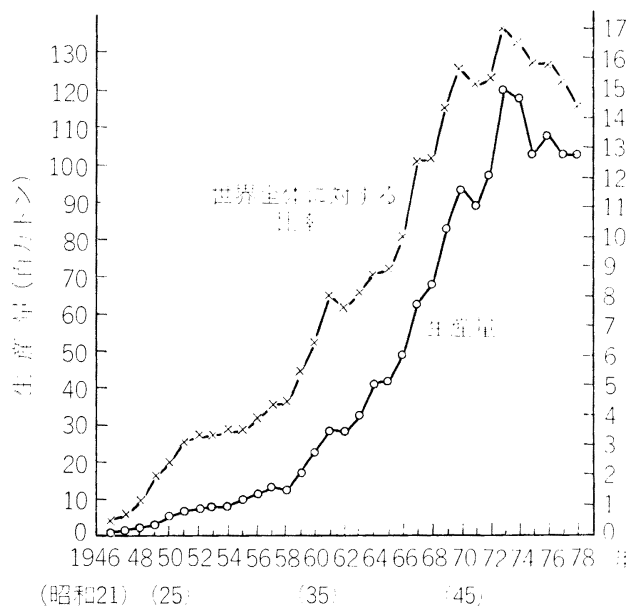

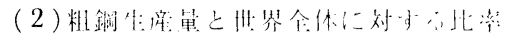

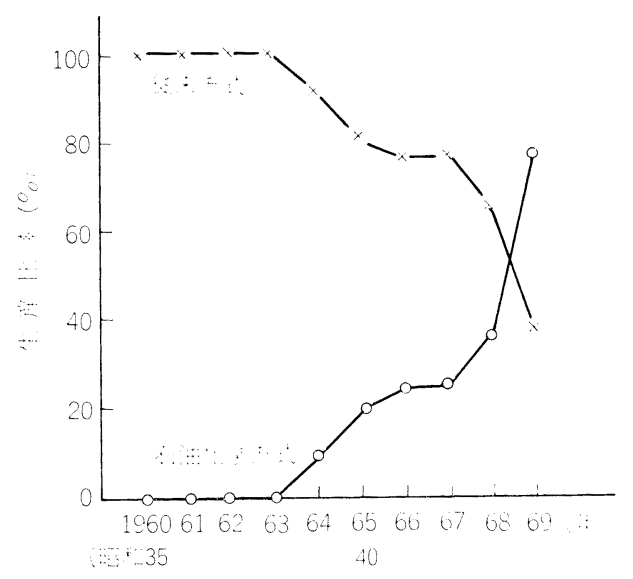

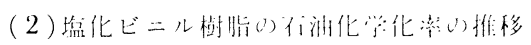

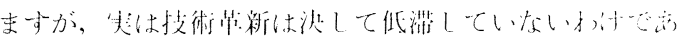

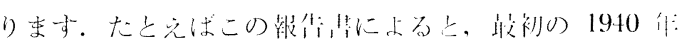
の:ンヒュータといらものは1少数门うドルにたのが.

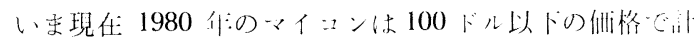

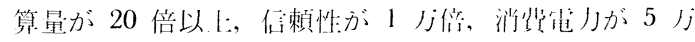
6000 分の 1, 大きさは 30 ノ分の 1 だということでダ. 大体ノのけけたで進少しているォけけです。 


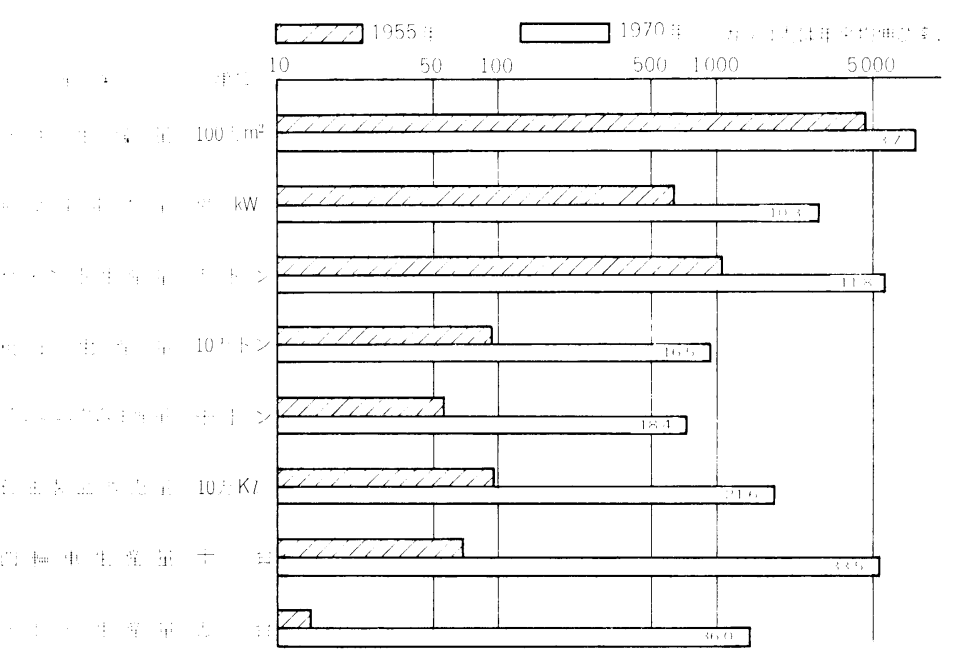

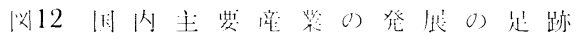

195.3 们:

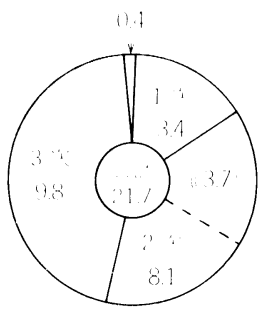

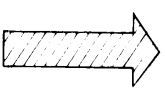

1). $10^{12}$
1970 作

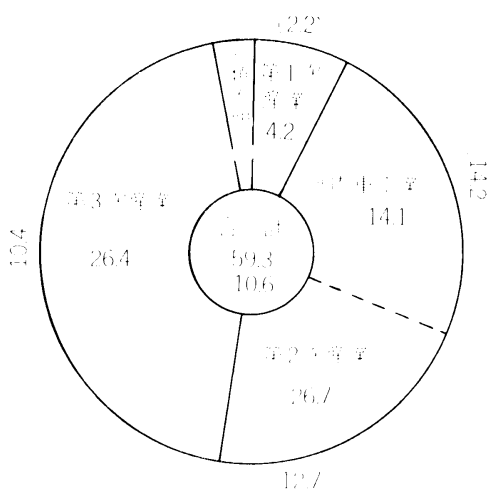

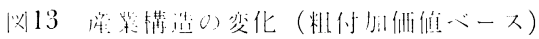

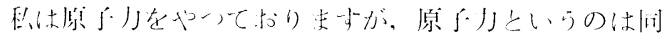

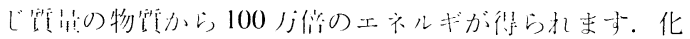

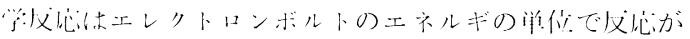

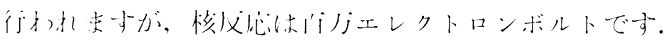

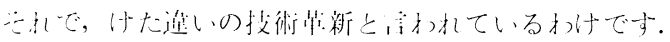

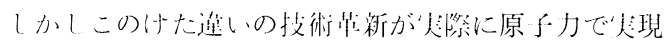

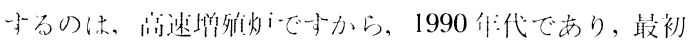

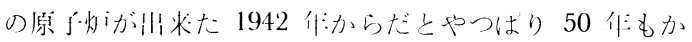

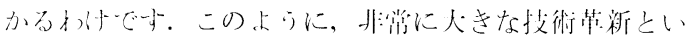

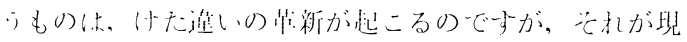

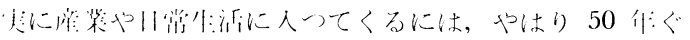

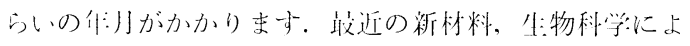
る、いわけるバイォテクノロジーなどもえらですが，技

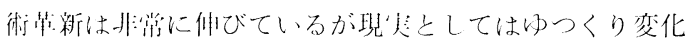
が现れるとらことです。.

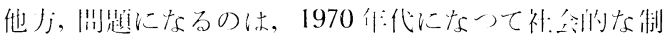

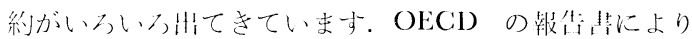

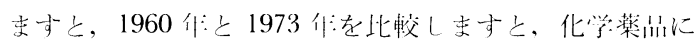
関してい总ば䉼しい製品の数は2 分の 1 に低トてていま

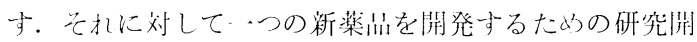

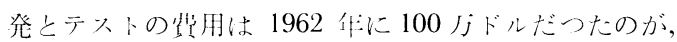

1974 年には 2400 ノおドル，1976 珄には5 400 万ドルに

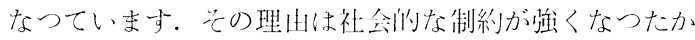

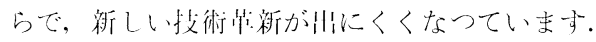

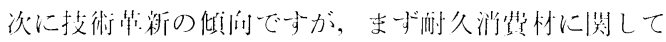

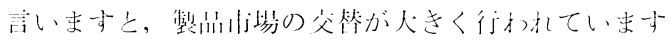
(表2).

たとえば，回動中などでは，新しい技術革新はほとん ぞなくて安全，排父规制，然䩀など新しい条件への対心 の技術が主になつています。文た生産方式の変化です 


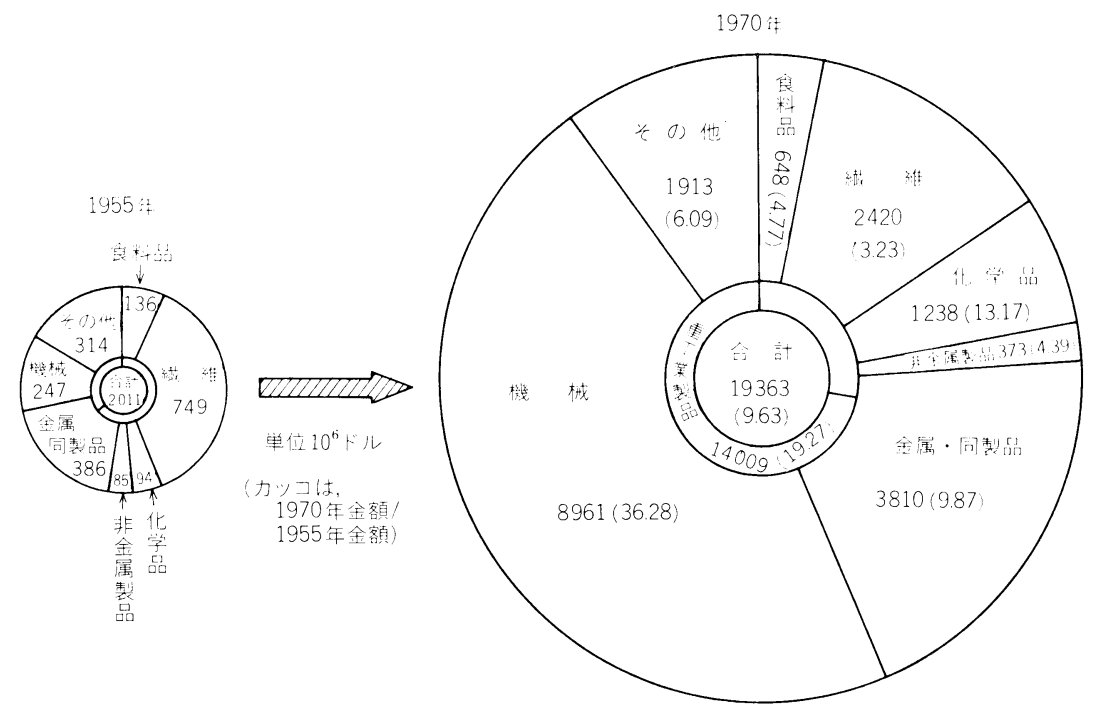

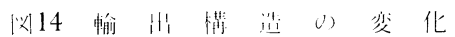

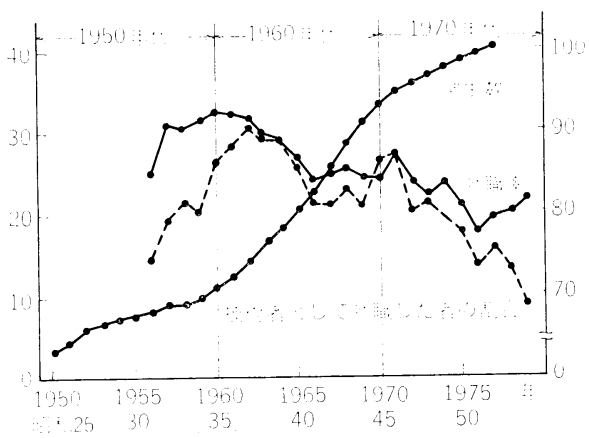

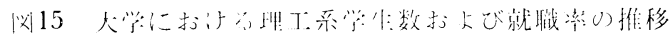

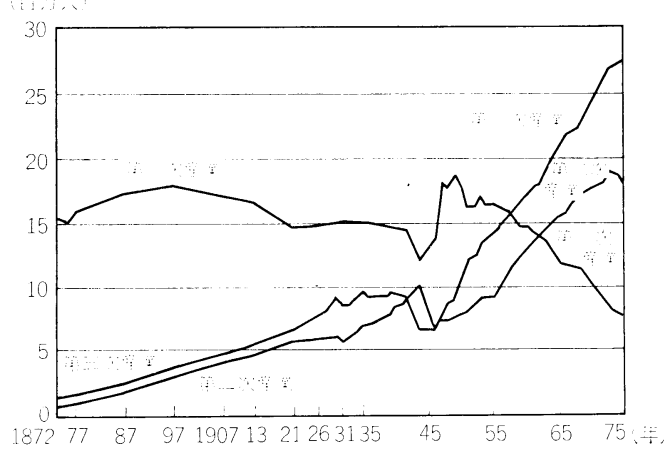

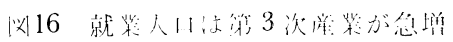

が、ロボットやマイコンで牛㨇)j式の介理化といいます

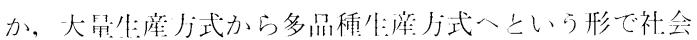
们，経済的制約条件に見合らた奶の技術草新が行われて

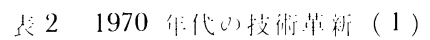

技術华衡

装们

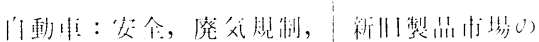
燃们

情尚方式

ロボット,

マイコン

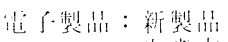

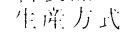
学濑集約 父代, 新興间上

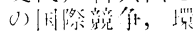
㑽・エネルド剌

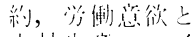

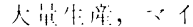
エンし)

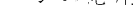

\section{|rot行,}

衣31970 作代り技術荤新（2）

\begin{tabular}{|c|c|c|}
\hline & 技術糔 & 紧 $\quad|1|$ \\
\hline \multirow[t]{3}{*}{ 中阔期 } & 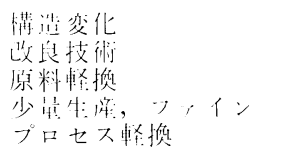 & 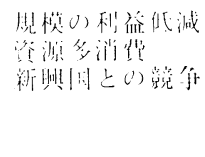 \\
\hline & 1970 作代ひ某利技術 & ( 3$)$ \\
\hline & 技術架䉼 & 紧安 \\
\hline 渠本財 & 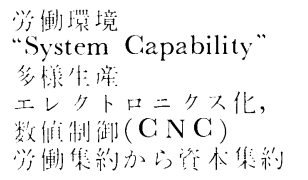 & 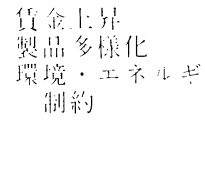 \\
\hline
\end{tabular}

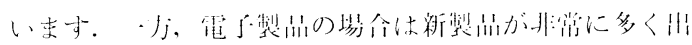
てきています。.

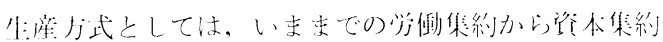
に移つていて大きな技術炗䉼が行われているという见う 


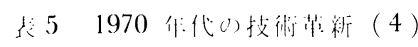

\begin{tabular}{|c|c|c|}
\hline & 技修革新 & 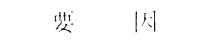 \\
\hline 神全阙遇 & 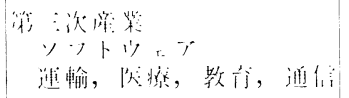 & 祙:会懐境り変化 \\
\hline
\end{tabular}

1) 剩技術转新

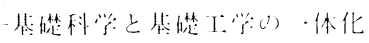

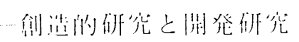

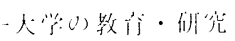

2) 技術阙焱体制

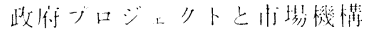

崔碟技術とプロジェクト

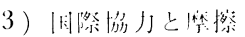

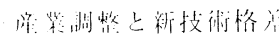

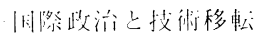

4) 祜会摔膛U变化

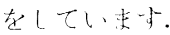

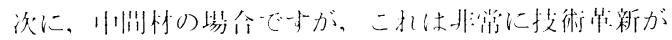

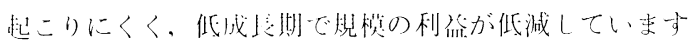

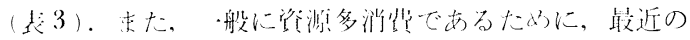

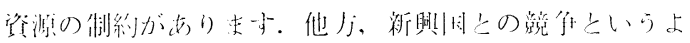

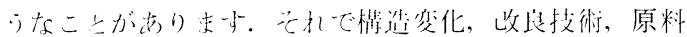

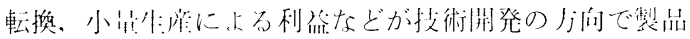
こしてはつァインケミカルとか, 特殊鋼などでありま

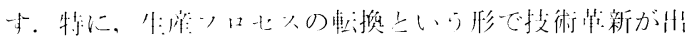
てい寺卢。

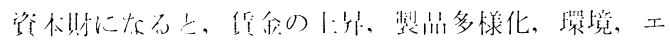

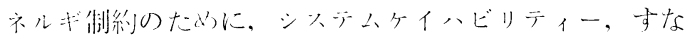

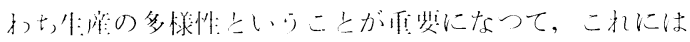
エレクトロニクン化，数们制御などに上り，学働集約か

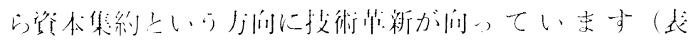
4).

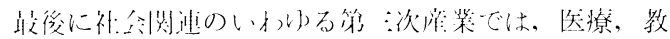

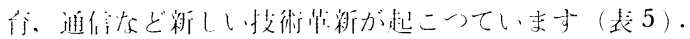

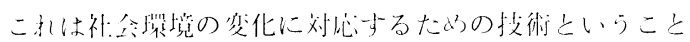
であります。

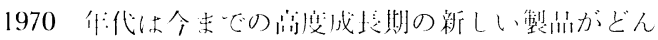

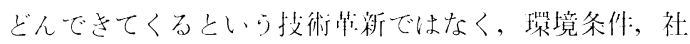

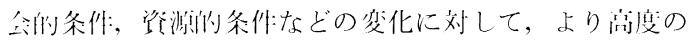

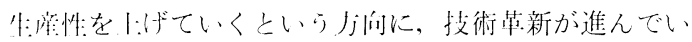

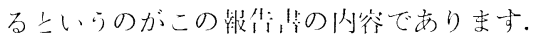

\section{1980 年代の課題}

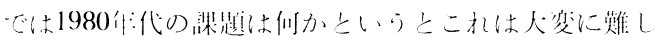
い间題であります。私なりにけしはげますと，第１は新

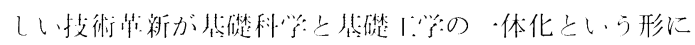
なつてくるといらことです（尤6）.

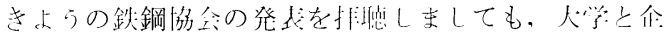

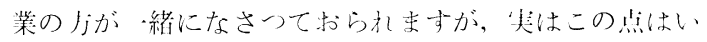

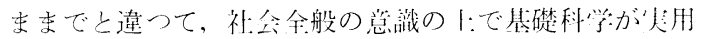

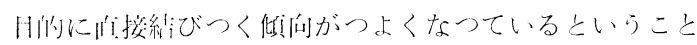

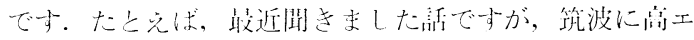
ネルギ研究所がございますが，この研究所は大きな加速

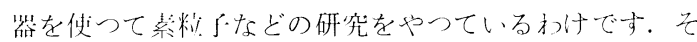
の音エネルギ研究所の所!代筑波の䭾でタクシーに乐つ て「だんなどこ一行くんですがと閌か子たときに槀エ

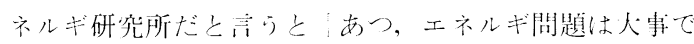
すからがんばつてください|と言わ孙たといらんです 权.これは般の人にとつては笑い話にならないかも

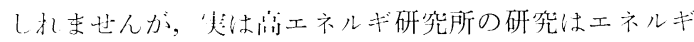
を消整して粆了をこわして研究をして书り、エネルギ の特库と全く関係がないといえるれけですから、エネ ルギばかり使つていて何も新エネルギは壯てこないれけ

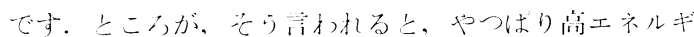

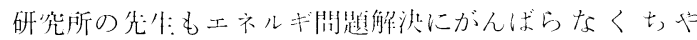

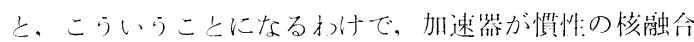
研究と関係があるかな，上いう话になつてくるのであり

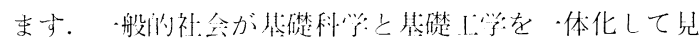
ているもいらことで，大学の教高，あるいは今後の研究 のありノに大きな変化が少えら机るのではないかと焽い ます。

㓣造们研究と開炎研究とい5焦に拀いて，往々にして 川本は生産技術に優机ているが例造的研究におくれてい

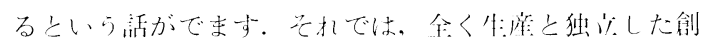
造们研究といらものがあり得るかどらかという䦌題があ

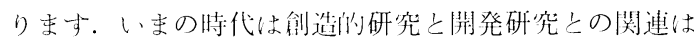

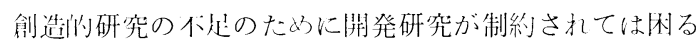
わけですが，一少逆に刢造们研究も哃発研究と結びつか ないとなかなかやりにくい侍代になつているのではない

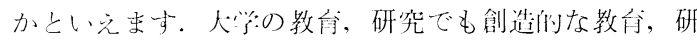
究を行うことは大変でありまして, 皀はビーカーとフラ 久ュでできたよらな研究も，いまでは高度の装監と技術 が必要になつてきています。ですから，1960 作代には大 学:では学術的な基碟研究はできたが，開発研究につなが るよらな基礎研究はほとんどやれなかつたと思います。

それで 1970 年代から 1980 年代に入つて，こ机が-.つ の閏題になつてきていると言えます。

てれから，第２は技術開発の体制の䦌題があります。 この.つは政府と才場機構の関係です．基盤技術とつ口 ジェクトの関係も閣題となります。先ほどから甘し、げ ているように果たして勝七孯を見つけら机るのかといら 間題にも测速があります。

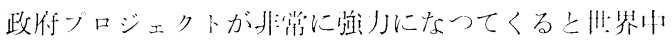
が同じ琴に賭けてしまら恐れがある。同じ哭としてたと えば核融合にみんな賭けて世界が協力した場合，この哭 が真けると世界中がダウンしてしまうといら伦険性があ 


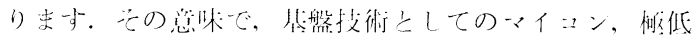

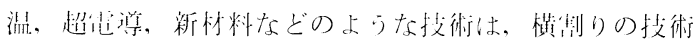

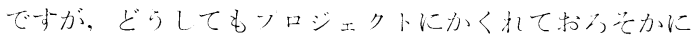

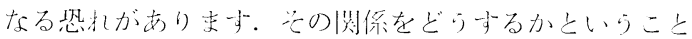
でず.

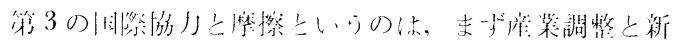

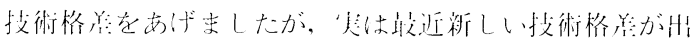

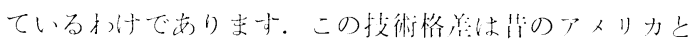

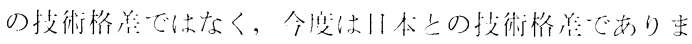
tr.

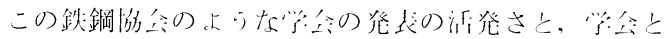

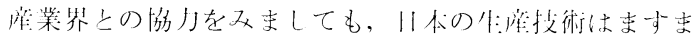

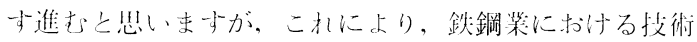

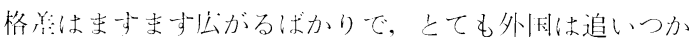

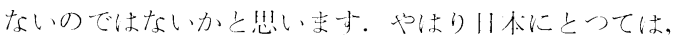

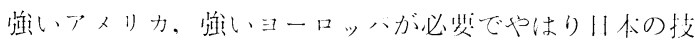

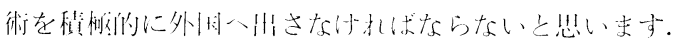

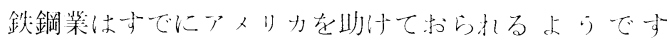

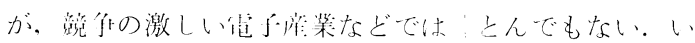

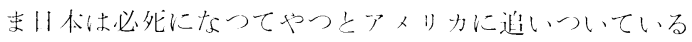

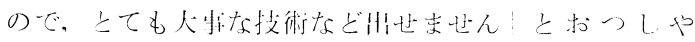

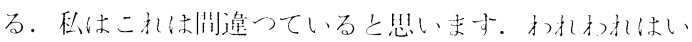
つも追つかけた沈䈍しかないものですから、すでに追越

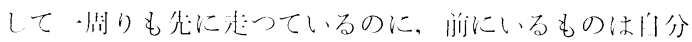

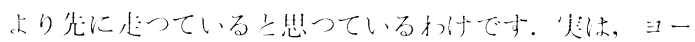

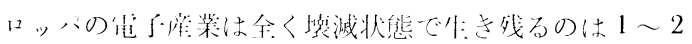

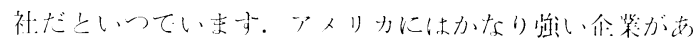
りますが。

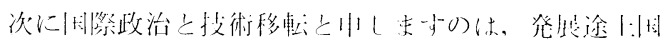

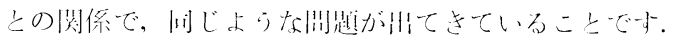

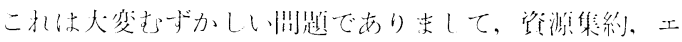

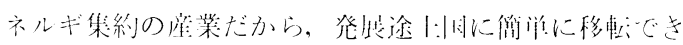

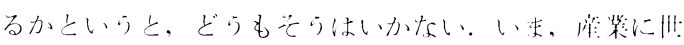

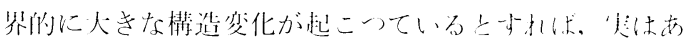

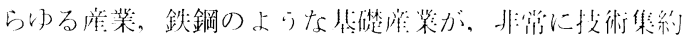

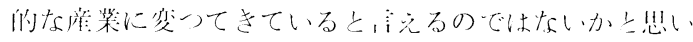

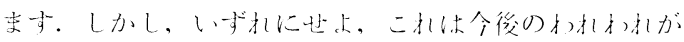

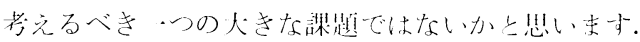

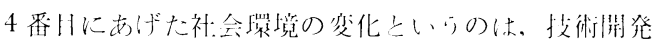

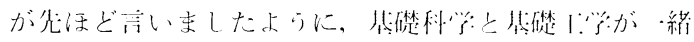

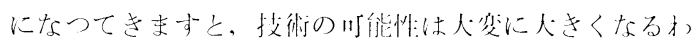

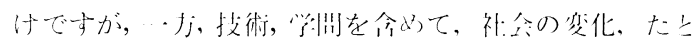

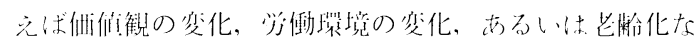

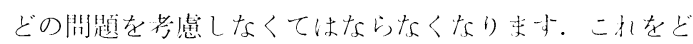

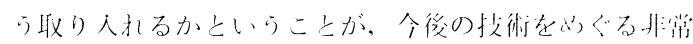

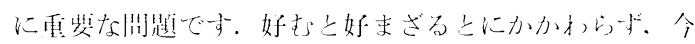

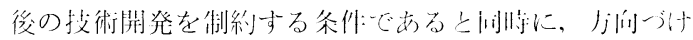

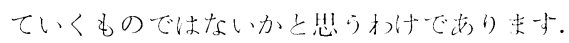

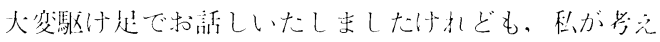

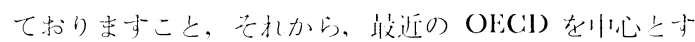

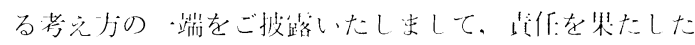
い上思います。 